\title{
FOOD AND NUTRITION IN ISLAM
}

\author{
By Mohammad Mazhar Hussaini
}

\section{INTRODUCTION}

Probably no topic has universally intrigued man more than food. Social and natural scientists are more and more involved and inlerested in the subject of food. studying man's food praclices and beliefs in dilfering culiures.

There is a science of nutrition and a practice of nutrition and the same word is used for both. Looking historically at the development of the field of nutrition, we have 10 hegin with the practice of nutrition.

In general the pracrice of nutrition is determined in inmumerable ways by social, cuitural and national traditions. moral commands and restriclions, individual psychological experiences and only incidentally by nutritional needs. However in case of Muslims. the nutritiona) praclices (as their every other action) are expected to be predominently determined by 1 he injunctions and regulations of lslam as outlined by the Holy Book of Qur'an and explained by Sunnah. More than 900 million Muslims of different nationalitics, societies and cultures of the world make this nutrutional practice unique.

With an increasing growth in Muslim population in United Statcs of America, there is an cqually increased need of identifying dielary regulations of Muslimsand understanding lheir lood behavior. There are more than 3 million Muslims in United Stales of Americat and it is as important to lood induseries, restaurants. airlines as it is to diefirions. nutritionists and food service personnel to become aware of the regulations of food and nutrition in Islam. The elhno-scientitic study reporled hercin reviews these regulations 10 entance the cuicural understanding between Muslims and non-Muslims.

While reviewing the Islamic nutritional pracrices in this study, the author has used the scientific data as a major applied tool for the better understanding of the Islamic spirit. The objective examination of the Islamic Revelation in the light of the discoveries of science will surely help readers appreciate the wisdom and applicability of Jslam.

\section{SIGNIFICANCE OF NUTRITION:}

Islam, satisfying the needs and demands of all times. wirnesses the importance of nutrition as rest of all aspects of life. It recommends eating of all that is good and pure. In this respect Allah says in the Quran:

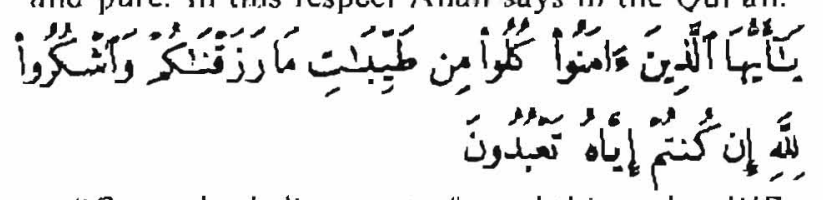

"O te who believe, eat of good things that WE have provided for rou and he grarefillo God if is is HIM le w'orship."

...Qurin. 11:172

Nutricional advantages have accrued lizrough the injunctions of Qur'an from the heginning of life as the Quran recommends mothers 10 nurse their ollsprings for two wholc ycars.

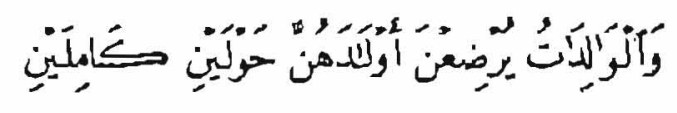

"The molhers shall give such us sheir offspring for wo whole lears"

...Quràn. 11: 233

tslam recognized the importance of infant nutricion some 1400 years age althougls the uniqueness and special valuc of human milk has been scientilically

\section{EDITORIAL NOTE:}

Food and nurition are very essential to human needs. Personality: Character is influenced by: she foods " person eals. Hence Istam has laid down great emphasis on the igpes of food to be eaten as well as on the quality and the means and meshods of oblainmg them.

In this arikle. Brother Muhammad Mashar Hussaini has laken a lead in wiriting on the lopic of "Food and Nutrmon in istam. "The artile is very' interesting, informasive and documentative from the Qur'an, the Sunnah as' well as from sciemufic records and facts. In so doing. Brother Husaim has plaved a positive role in bridging the gap berween science and religion. He also bridged the gap beneen the Muslims and non-kuslims as the arricle is very helpful to boih groups of people.

Brolher Hussaini ix w be commended for his mone, his bravity and his leus in writing his article. We hope and prav. that the wiselom will he shared th every reader and benefil will be stansmirted to every concerned person in the world. Mu! Allat bless the efforts of Brother Hussaini and make them frutiful. May Allah bless the efforts of every concerned perion whose ains ind ohjervises are for the pleasure of Aliah. Ameen.

Ahmed H. Sakr, Ph.D. 
recognized in more recent years. Breast feeding is a natural system. a simple normal function of supply and demand that best serves mother and baby.

Molher's milk cannot be duplicated because any substitute even though composed of all things now known to be reeded, will be lacking in some essential factor nol yel discovered in human milk. The eighth Report of the Joint FAO/WHO expert Commizce on Nutricion (1971) reported that even in less well fed communities of the world poorly nourished mothers lactale surprisingly well producing milk of normal protein content in quantities sufficient 10 ensure growth in exclusively breast-fed infants for 4 to 6 months. It has been shown that the breast feeding constitutes a signiticant protein suppliment during the first iwo years of life.

Considering the extra nutritional requirements of expectant and nursing mothers, Islam relieves them from observing the obligatory fasting in the month of Ramadhan'. They can make up for the lost obligatory fasts when they allain normal health.

Considering the necessity of geriatric nutrition. Islam recommends old people to compensate their obligatory fasts with feeding poor and needy. The importance of therapeutic nutrition is realized and the provision is made for the sick and the convalescent to make up for their lost obligatory fasts when they resume normal health.

Islatm recommends that its followers obtain and consume food of nutritional quality. In this regard, Allah salys in the Qur'an:

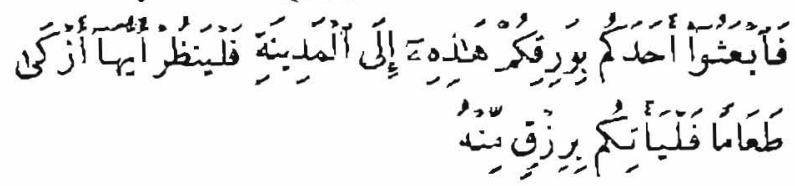

"Now send one of you with your silver coirl inlo the cilj, and let him see what food is purcs there und bring vou a supply there of ..."

...Quran. XVll1: 19.

Maintaining a balance betwecl) the recuirements of body and soul. Islam has laid down simple and reasonable dietary rules. Accordingly when Islam allows to eal all that is pure and nutritious, it also prohibits its followers certain calegories of food and drinks..

\section{LAWFUL FOODS}

for Musims. all lypes of loods and drinks are considered lawhul unless it is specilically prohibited. as the Quran stated:

Ramadhan: The ninth month al the Islanic lunar calcndas. Fasting is obligutury on ever' Muslim who is not a minor or insune in the monch of Ramadian cuch year

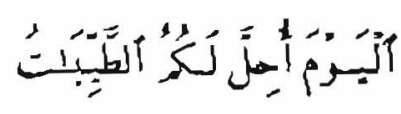

"This day all things good and pure are made lawiul unio you."

(Qur’an. V:6)

Musilims are supposed to eat lawrui (HALA L) rood. The Qur'an uses the term "HALAL" for lawful food which has double significance

a) Food to be earned lawfully.

b) Food should conform 10 the Islamic laws relative 10 the mode of slaughtering.

The Islamic mode of slaughtering consists of mentioning the name of ALLAH' on the animal or the bird during slaugher. In this regard Allah says in the Qur'an:

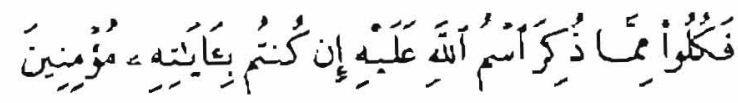

"So eat of meals on which God's name hain heen pronounced if you have faith in $\mathrm{His}$, vigns."

(Qur'an, VI: 118)

Muslims are reminded that God has command over the life of all creatures and they are taking the life of animal or bird by God's permission for the sole purpose of food for eating.

Slaughtering involves slitsing of throat. wind pipe and the jugular veins in the neck whoul culling the spinal cord. The purpose of this is to dran out all the blood which would olherwise serve as a good medium for the bacteria 10 grow. The spinal cord must not bc cul because the nerve fibres 10 the hearl may be damaged during the process causing cardiac arrest. stagnating the blood in the blood vessels of the a nimat.

\section{PROHIBITEN FOODS:}

Among the calegories of lood and drink that are forbidden according 10 the Quranic injunctions are

1) Meat of a sinal that dies of irself (carrion).

2) Blood that is poured forth as distinguished from the blood adhering to fiesh or other orgin.

3) Flesh of swine including all the products and byproduces prepared from swine.

4) Food on which any olber name has becn invoked besides that of God.

5) Intoxicants.

The first four categories of lood are lorbidden according to the following versc in the Qur in:

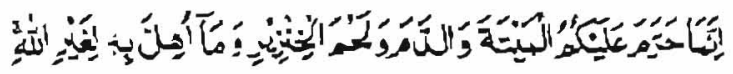

'ALLAH: The appropriale name of God used in Quran. 
"He halh only forbidden you dead meal and hluscl and the flesh of swine and that on which any viher name has been invoked besides that of ciod."

(Quràn, II:173)

The lifth eatcgory of prohibition includes als the intoxicants. as Ciod says in the Qurian:

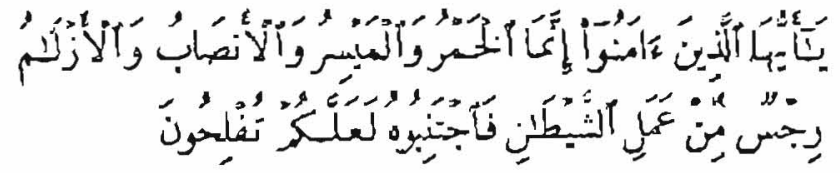

"O Ye who believe! imoricans and gambling are an abominasion of Sulan is homdinurk. Esches. wh ahuminalion that le mal prosper."

(Quran. V:9.3)

\section{SOME OF THE SCIENTIFIC FINDINGS:}

The first calcgory among the lorbidden food item is dead mcat. Dr. Kazim (1971), in his article. "Medical Aspects of Forbidden Food in Islam, "commenting on the discaves calsed 10 man by animals which dies of itself presented a parrial list of diseases as causes, such as: Anthrax bacillus cauning malignant pusiules. Brucellosis causing undulant fever, Pasturella mullicede causing hemorrhagic sepliccmia. l.eptospirosis species causing lever. jaundice. headache, elc.

The steond calegary is that of the blood. I is a good medrum for flourishing and multiplication of bacleria and other micro organisms. When eaten, it might iransmit the micro organisms into the body alfecling the health adverscly.

I he thiro category among the prohibitic foods is the flesh of swine and. by cxtension. all the products and byproducts of it. Up uncil a couple of decades ago llere was no apparent scientific reason as to why the pork should not be used as lood. Then a micro organism called trichinesla. was found in the muscular lissue as the causc of trichinosis in humans. It was thusght io be the reison why pork was prohibited. But when. by pasteurization process the problem ol irichinella was climinated there was no apparent reason for prohibition. Recemly. howcver, il was lound that the large fat content of the pork contributed in the development of obesity, atheroscholorisis etc. in man.

The prohibition of fond on which any or her name has been involed besides that ol God emphasizes the very fundamental crecd of Muslims that there is no God but ONl: All the intoxicants are forbidden ins islam as cind ordained to crelicw such abomination.

An Arabian al-chemist by the name of Jabir Ibn Hatyan is generally credited with the discovery of the process of distillation of alcohol in 800 A.D. HC suggested the name "Alghul" (meaning "ghost' or 'evil spiril in Arabic) for i1. Accordıng to Dr. Marvin A. Block. an duthority on alcoholism. every lisiue and every organ is allected by alcuhal in onc way or other. When carried in the bloodstream, it reaches praclically every tissue of the body. The World Healih Organization of the United Nations described alcoholism as a chronic illness that manifests itself ats a disorder of behavior... The annual loss to the cconomy of USA resulting from alcoholism is cstimated at 15 billion dollars.

\section{EXCEPTIONS:}

In matlers of food as in all other mallers the mission of Lslan is to avoid the extremes of lawlessness on one hand and extreme formalism on the other. Muslims are pernitled to eat or drink unlasvful foods and drinks only under exceptional condilions as follows:

a) By mistake

b) If one is compelled to do so without wittul disobedience. In this regard. Allalt says in the Qur'an:

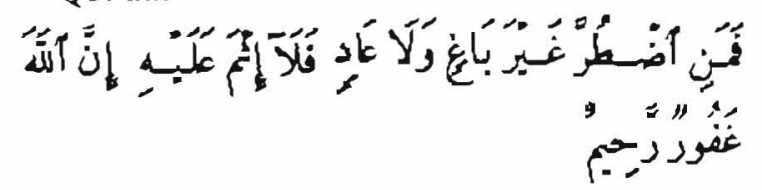

"bul if one is forced b!" necessit!, withour whlful disobedience. nor iransgressing due limirs then is he guilless for God is of forgiving. MOST MERCIFUL"

(Quran. 11: 173)

c) For fear of dying of hunger or discase. Allah says in the Qur'an:

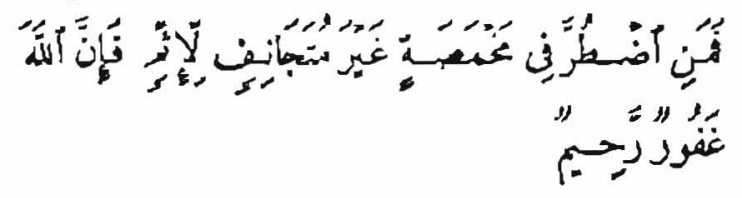

"but if any is forced by hunger with no inclination 10 irunsgression, God is incleed of forgising. MOST MERCIFUL."

(Qur'an. V:4)

d) Seafood is exceptional to the category of forbidden food of dead meat.

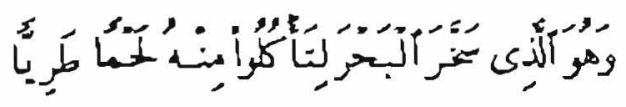

"And He it is who has constrained the sea to be of service thar you eal fresh mealfrom ihence...."

(Quran, XVI: 14)

Sea food is lawful whether it is caught alive or found dead, unless it is spoiled or poisoned. According to a Sunnah reported by Alrmad and Ashab Sunan, "The water is pure and clean, and the dead sea food is Hălal." 
ISLAMIC DIETARY HABITS:

Eating. like any other act of a Muslim, is a matter of worship and begins in the name of Allah'. Islam reminds Muslims that the loods and drinks are the provision of Allah provided to them for survival and lor maintaining good healih.

Cleanliness and hygiene are emphasized to the exrent lhat it has been considered a part of Iman (faich).

Eating logethes and sharing of food and resources with relatives, friends and ncighbors is recommended.

Pcoples starve in several areas of the world roday. not because there are more people on carth than can be led. but because the food that is produced is nor equitably distributed.

It is recommended that we not drain a glass of drink in onc altempt but drink small amounts of it at intervals to avoid chok Ing. Islam expects people to cac to maintain health. Overcaling is not encouraged and waslage of food is condemned. Allah says in the Quran:

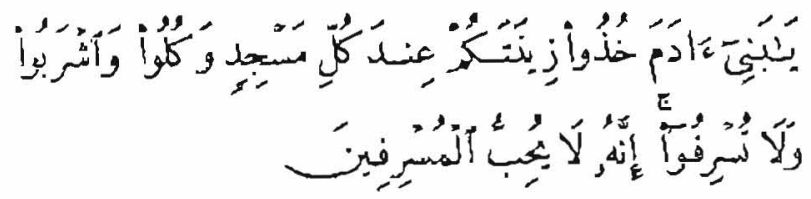

"O children of Adam! look to your adornment al "ver! place of nership. and eal and drink, bul be not prodigals. Lo! He loveth nor the prodigals. "

(Quràn. VIl: 31)

Prophel Muhammad (Peace be upon him) is reporled to have said. "Eat less: you will be healthier." Muslims are advised 10 cal and drink not more ihan I wo-thirds of their normal capacily.

A very interesting study with rats has been conducted dealing with the onsct ol diseases, longevity and morlalizy as influenced by the levels of food inlakes. On liberal recding. the rats allained large size and developed obesity. When food inlake was reduced by $33 \%$ to $46 \%$. lat accumulation was prevented with litule retarded eflect on skelctal growlh. l.ongevily was extended and the anset of diseases was delayed. In man there is a considerable evidence that overweight and obesily predisposes to shoriened life expectancy and to the development of cardio-vascular and renal disorders and hypertensions. Accordine is the National Health Survey ipproximately half of the adult population of America is classified as hypertensive and about $20 \%$ to the population is considered to be obese.

IThe Arabic Ierm is "BISMILLAH" which is repeared al the beginning of every act by a Muslim.

\section{FASTING IN ISLAM}

Deprivation of food sluff either accidental or deliberate is a common event in human exisltnec. Volumtary abstinance lrom food or from certain kinds of lood for a duration of time has found widespread acceptance in all religious systems as fasting. although the motives vary.

Fasting in Islam involves abstinence from three primal physical needs of human beings - lood. drink and sexual gratilication. from dawn to sunset with the intention of lasting in the montl of Ramadhan each year. It is obligatory on every Muslim who is nol minor or insane.

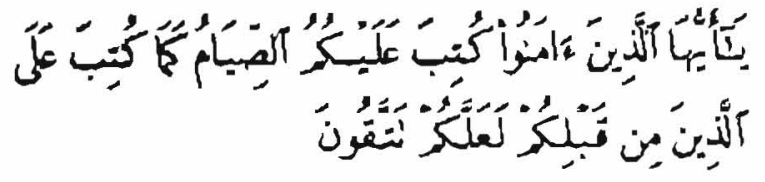

"O you who believe! Fasing is ardained for you ... so that you may remain conscious of God."

(Quran, (I:) 83)

Control or abstintnce from the satisfaction of thirst which is basic to our very existence. hunger which has always played a major role in determining the action and atitude of man and sexual gratification which is universally held to be onc of the pleasures of lile are intelligently used its the means to arrive at the state of purity and holiness.

\section{SCIENTIFIC STUDY ON FASIING}

No erhno-scientific study has been lound on Muslim religious fasting in the literature. However following is a brief review of fasting experiments on animals which in some way resemble the Muslim rasting pattern.

Following a fast of abous is hours in an experiment on rats, it has been reported that there is an increase in their absorptive capacity of small intestine and an enhancement of tissuc uprake of amino-acids. While studying the effect of restriction of bolk food and watter. organ water contents in thirsty and slarving rats has been found to be basically more normal than in those starving rats with access to water. Scientilic studies concluded that presumably in voluntary Jehydration the frec circulating water of the gut is being withdrawn and tissue dehydration does nol slart unti) the gut water has been largely utilized. This provides an initial buffer against dehydration.

In the year 1974 during the month of Ramadhan (Seplember 18th through October 16th) the author conducted a dietary analysis of Muslim students of Norlh Dakota State University. Fargo, Norlh Dakota. It was found that the dietary intake of Muslim students was adequate during lasting alt hough the energy intake was at or near the two-f hird 
Wel of NRC-RDA.'

In orher words fasting involves just a change in feeding schedule ralker in the amount of lood consumed. By no means does this practice lead to the inadequatc food intake. Instead food may be more varicd and nutritious during Ramadhan fasting than that consumed at other limes of the year.

\section{RECOMMENDATIONS}

As Mustims are a part of many cultures. dhey have an opportunify 10 make significant contriburions to the nutruional praclices of the world. The lslamic injunctions have made the conseyuences of these practices moral and spiritual. Thlure is a Iremendous scope of research in the sphere of Muslin cultural nutrition. A large number of Muslims miglating to the non-Muslim environments are confromled with a challenge to preserve their Islamic identity.

Muslim scientists in general are recommended to explore the scientific icasoning behind the Islamic practices and to establish the lact that Islam is a complete and practical colce of life.

INRC-RDA: National Rescarch Council-Recommended Daily Allowarices.

\section{REFERENCES}

I. Ali. A.Y. The Holl Qur'an. Texi. Translation ind commentary, Beirut, Lebanon: Dar Al Arabia. 1968.

2. Berg, B.N. and Simms, H.S Nurrition and Longevily in the Rat II. Longevity and Onsce of Diseases with Different I evels of Food Inlate Jenumal of Nurition. $1960.71 .310-320$.
3. Fitzsimons, T. 'Thurst, Physiological Reviews, 1972.52. 468-561.

4. Hegsted. D.M. Nutritional Reyuirements in Disease Journal of American Dieteric Association. 1970, 56:4, 303-307.

5. Hugo, E. Gallo-Torres and Jacqucline, L. Comparison of the Portal Absorplion of Protem and Small Peptides in the Fed and Fasted Rat. Journat of Nutrition, 1973, 103, 1745-1755.

6. Hussami. M.M. Foud and Nutrivion in Islam. Journal of Rabelal Al-Alam Al-Is/anii (Muslim World League, Mecea), 1975, 3:1, 37-38.

7. Hussaini. M.M. A Dietary Study of NDSU Muslim Siudents During Fasting in the month of Ramadhan. M.S. Thesis (Unpublished). 1974.

8. Newman. R W. Why Man is Such a Sivedly and Thirsty Naked Animal: A Spectacular Review, Journal of Biology: 1970. 42, 12-27.

9. Oatley. K. Changes in Blond Volume and Osmotic Pressure in the Production of Thirst. Nature. 1964. 202. 1.341 .

10. Sakr, A.H. Dictary Regulations and Food Habits of Muslims. Jinurnal of the Amercan Dieteru Association. 1970, 58. 123-126.

11. Knutsson. K.E. and Selinus, R. Fasting in EuthopiaAn Anthropological and Nutritional Study. American Journal of Clinical Nutrition. 1970. 23. 956-969.

12. Kazim. E. Medical Aspecrs of Forbidden Food in Islam. Al-litihad. 1971, 8, 4-6.

13. Jelliffe, D.B. and Jelliffe, E.F.P.. The Uniquencss of Human Milk. WHO Chronick. 1971. 25. 537-546.

14. Food and Nutrition Board. Kecommended Dielary Allowances (Eighth Edition. Revised 1974). Wratinglon. D.C. Narional Rescarch Cuuncil. Nalional Academy of Sciences. 1974.

15. The Joins FAO/WHO Expers Commintes un Nusrihion. Eighth Reporl. Geneva (World Healch Organzation Technical Report Series No. 477). 1971.

16. Wilson. A.S., Burnstein. L. and Torrel, E.S. Effect of Feeding schedules on Growth in Rats. Growth. 1968. 32. $75-81$. 